\title{
Consumer Ownership of Natural Monopolies and its Relevance for the Green Transition: The Case of District Heating
}

\author{
Søren Djørup ${ }^{1, a,}$, Ole Odgaard ${ }^{b}$, Karl Sperling $^{c}$, Henrik Lund $^{c}$ \\ a Norwegian Research Center NORCE, Professor Olav Hanssens vei 15, 4021 Stavanger, Norway \\ b Paul-Petersensvej 10, 2820 Gentofte, Denmark \\ c Department of Planning, Aalborg University, Rendsburggade 14, 9000 Aalborg, Denmark
}

\begin{abstract}
District heating is important for the transition to sustainable energy systems. In order to implement district heating, consumers' trust and acceptance of this technical monopoly structure is necessary. This necessity leads to the question of price regulation and ownership in the district heating sector, since these institutional structures are the measures for creating trust and acceptance. This article is based on a Coasian approach, where information costs and concrete institutional structures are at the centre of the analysis. This approach is applied for the purpose of understanding the role of consumer ownership in the district heating sector. An ownership model which has been shown to be the most efficient in Denmark. Through a detailed empirical case study, it is shown how private commercial companies have avoided the state regulatory monopoly price regulation and inflated consumer prices. The case study also describes how changes in ownership immediately led to price reductions. It is concluded that the consumer ownership model has played a vital role in getting price regulation to succeed and thereby consumers to trust and accept the district heating systems in Denmark. This result is an important contribution to heating policy development as well as monopoly regulation theory.
\end{abstract}

KEYWORDS: District Heating, Monopoly Regulation, Ownership, Transfer Pricing, Coase

\section{INTRODUCTION}

The Green Transition of the European energy supply is putting district heating regulation on the agenda. First, this policy area is important for establishing new energy supply systems because district heating has a very large technical potential across Europe (Connolly et al., 2014; Möller, Wiechers, Persson, Grundahl, \& Connolly, 2018; Persson, Möller, \& Werner, 2014). Second, the transition towards integrated renewable energy systems may bring about new questions regarding regulation of existing energy supply systems.

Denmark is a country with a high share of district heating in the heating supply and many years of experience with district heating regulation. This paper will look at the consumer ownership model that is in place for a majority of Danish district heating systems. It analyses how this ownership model works and how the model fits into the Green Transition.

Questions of ownership models in the Green Transition have been investigated in many studies. Outside the district heating monopolies, several papers have addressed the influence of ownership structures on wind power acceptance, among others (Barry \& Chapman, 2009; Devine-Wright, 2005; Warren \& McFadyen, 2010). Gorroño-Albizu et al. argue that citizen ownership has had an important role for the investment in and implementation of decentralised sustainable energy technologies. The study helps to understand the diversified spectrum of ownership models by describing the empirical characteristics of cit- izen ownership models for wind turbines and district heating systems in Denmark in the period of 1975-2016 (Gorroño-Albizu, Sperling, \& Djørup, 2019). The role of communities and citizen involvement in energy supplies have also been studied in other national contexts (e.g. Hoicka \& MacArthur, 2018; Kooij et al., 2018; MacArthur \& Matthewman, 2018; Rogers, Simmons, Convery, \& Weatherall, 2008). Based on the Danish electricity distribution sector, Hvelplund and Djørup argue that consumer ownership of natural monopolies historically has played an important role in keeping prices low and thereby providing financial 'space' for innovation in renewable technologies. Further, the article presents the hypothesis that consumer ownership will play an important role in smart energy system innovation, where a high degree of coordination across sectors will be necessary (Hvelplund \& Djørup, 2019), while Gorrońo-Albizu takes it a step further and investigates the question of whether local, cross-sectoral consumer ownership may improve efficiency (Gorroño-Albizu, 2020). Meade and Søderberg address consumer ownership through an empirical study of the electricity distribution sector in New Zealand. They conclude that consumer ownership is associated not only with lower prices, but also higher quality, efficiency and welfare (Meade \& Söderberg, 2020).

Earlier studies have highlighted a statistical correlation that indicates that the consumer ownership model is the most cost efficient model under the true cost regulation that applies in the Danish district heating sector. The true cost price regulation principle implies that the heat price consumers pay cannot be higher than the true cost of supplying 
this heat. This price regulation principle can thus be perceived as a not-for-profit regulation, but has also been called a 'consumer profit' regulation, since any realised profit within a certain year has to be paid back to consumers through reduced heat bills in subsequent periods. It will be analysed below how and why consumer ownership historically has been more cost efficient than private commercial ownership structures, addressing the question: What lessons can be drawn from the Danish experience with ownership models for the future regulation of district heating in Denmark and Europe? The paper will thus attempt to identify causalities in the institutional structures that can explain statistical correlations - for the purpose of providing learnings for district heating policies.

The role of district heating in the Green Transition is identified by reviewing state-of-the-art literature on the strategic potential of district heating in relation to the Danish and European decarbonisation goals. The theoretical approach also contains some economic lessons, primarily drawn from Coase and Hayek. These theoretical lessons are then put into the context of the policy problem at hand: How to regulate district heating monopolies. It follows from the theoretical approach that detailed case studies are necessary to understand how different institutional settings work in practice. For the present purpose, the focus of our cases is on the influence of ownership structures on the effectiveness of price regulation.

A previous econometric analysis will be supplemented by detailed case descriptions where the efficiency of the district heating price regulation under different ownership regimes is analysed. These qualitative empirical analyses are an important supplement to the theoretical literature on regulating energy supply monopolies, since they provide lessons from a concrete institutional setting where transaction and information costs are a major factor for overall economic efficiency.

The paper concludes by combining the knowledge of strategic district heating potentials with lessons drawn from historical experiences regarding ownership models. It is concluded that the consumer ownership model has been vital for a well-functioning price regulation in the Danish district heating sector, ensuring consumer trust. Consumer trust is a basic prerequisite for achieving the environmental and economic benefits from district heating systems in renewable energy systems. Likewise, the cases described in the text illustrate how private commercial ownership may undermine the strength of state regulative power, which in turn undermines consumer trust and prevents the implementation of sustainable and efficient heating infrastructures.

\section{THE PROBLEM AND HOW TO THEORETICALLY APPROACH IT}

Before diving into the case study, it is important to outline the theoretical approach to the problem at hand. The theoretical approach can be summarised by establishing the following five key points:

1) The Green Transition of the energy system is dependent on district heating

2) District heating is dependent on consumers' trust

3) Consumers' trust is dependent on price regulation
4) Price regulation is dependent on the provision of information

\section{5) The provision of information is dependent on ownership}

This section establishes a theoretical basis for the overall aim of the article: To clarify and highlight why ownership is important for the implementation of district heating systems and thereby also for the Green Transition. This will be done by first describing the role of district heating systems within the perspective of the Green Transition, and second, by describing a theoretical approach to regulatory problems.

\subsection{DISTRICT HEATING SYSTEMS IN THE GREEN TRANSITIONT}

Recent developments in energy systems research identify a central role for district heating systems in the ongoing decarbonisation aspirations. Both in Denmark and across Europe, significant potentials have been documented.

The Heat Roadmap Europe studies show the benefits of district heating to be valid across the whole European continent (Connolly et al., 2014; Möller et al., 2019; Paardekooper et al., 2018). To realise the full potential documented in this research, thousands of new district heating systems will have to be established in this decade across Europe.

For leading district heating countries, such as Denmark, the $4 \mathrm{DH}$ research project has developed the concept of $4^{\text {th }}$ generation district heating $(4 \mathrm{DH})$ as a technical strategy for transitioning thermal infrastructures into renewable energy systems with the highest efficiency (Lund et al., 2014) (Lund et al., 2018). This strategy is characterised by a lower distribution temperature (going from $-90 \mathrm{C}^{\circ}$ towards -55 $\mathrm{C}^{\circ}$ forward temperature), which provides higher energy conversion efficiencies and improves the feasibility of a wider range of sustainable heat sources - all of which contribute to reducing fuel consumption in primary energy supply. To achieve these technical benchmarks, system development has to be coordinated. System development along the $4 \mathrm{DH}$ route involves investments and upgrades beyond the managerial control of the district heating company (Djørup et al., 2020). Particularly, heat savings in consumers' buildings and efficiency improvements in building installations will be important in order for district heating companies to achieve lower distribution temperatures (Krog, Sperling, Svangren, \& Hvelplund, 2020). Temperature reduction is therefore at the core of the $4 \mathrm{DH}$ strategy and central to sustainable development of the energy system.

\subsection{THEORETICAL APPROACHES TO REGULATION}

Consumer acceptance is a premise for the implementation of technical advances in the heating sector. This acceptance is often perceived as challenging when the right regulatory infrastructure is not in place. The regulatory problem that the regulation should address is characterised by what is traditionally termed a condition of "natural monopoly". This condition is established by economic circumstances, primarily that the district heating grid is so capital intensive that having several competing grids within a certain geographical area is economically unfeasible. Thus, the company that owns the infrastructure is not in a 


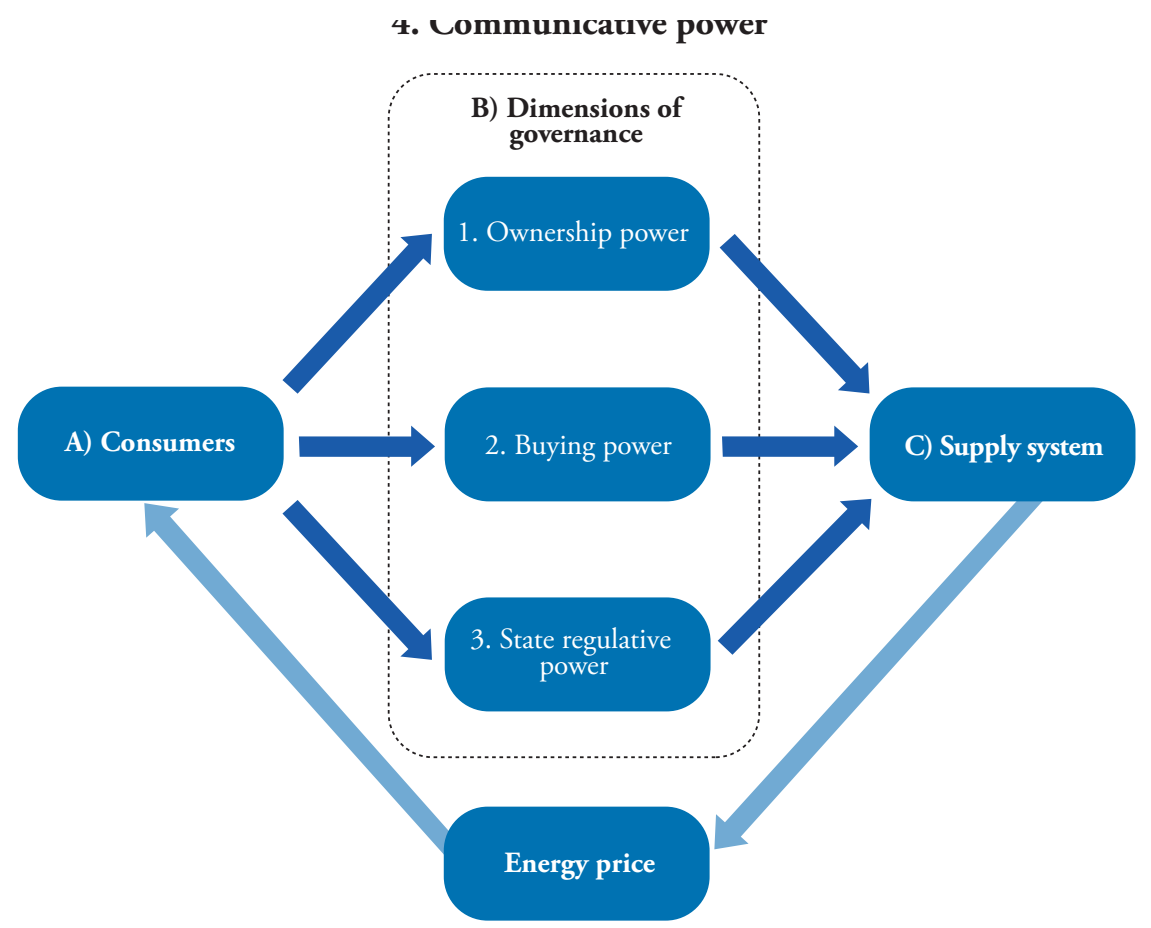

FIGURE 1. FOUR DIMENSIONS OF POWER IN AN ENERGY DISTRIBUTION SYSTEM. SOURCE: HVELPLUND \& DJØRUP (2019).

situation where it competes with other similar services. In theory, the district heating monopoly can be exposed to competition from single house solutions, such as individual heat pumps and biomass boilers. However, in practice, this competition is often restricted by other factors (Odgaard \& Djørup, 2020).

The theoretical approach to regulation is based on four basic dimensions of regulation through which consumers can control the monopoly, namely 1) ownership power, 2) buying power, 3) state regulative power and 4) communicative power (see Figure 1). While buying power and state regulative power are often in focus in mainstream economic textbooks, the ownership power and communicative power dimensions are often overlooked or neglected.

Classic economic textbooks often treat regulatory problems through a model with a binary choice between "market" and "regulation", that is, between buying power and state regulative power. In the Danish energy sector, ownership power has historically been an important regulative strategy as, for example, district heating grids have been owned and operated primarily by consumer-owned or municipality-owned companies.

Similarly, the communicative power element is shown to be important since it, for instance, involves transparency of costs and prices, facilitating comparison of the performance of different district heating companies. Communicative power tends to be limited in private company settings due to the necessary protection of commercial interests, whereas these interests are practically non-existent in consumer-owned and municipality-owned district heating companies. Thus, the sharing of information on costs, prices and technical data with consumers, the regulator and other district heating companies is a widespread practice.

The absence of ownership power and communicative power in economic textbooks can be linked to the critique of neoclassical econom- ics put forward by Hayek and Coase. While neoclassical economics works under the assumption of full information as a default condition in the theoretical approach, Hayek and Coase use the condition of imperfect information as point of departure for theoretical analysis. Their work has been pioneering and many scholars after them have analysed different perspectives of the role of information and information asymmetries. However, for the present purpose, their fundamental theoretical building blocks are deemed adequate for constructing a theoretical framework that helps understand the role of ownership in Danish district heating.

Coase' work on transaction costs is based on such an information problem where transaction cost is defined as the cost of using the price mechanism (Coase, 1937, 1960). That is, there is a coordination cost of the market organisation, which is connected to the cost that the market participants incur for acquiring adequate levels of information. These costs of using the market - the transaction costs - hamper the efficiency of markets compared to the neoclassical ideal model. And in turn, the transaction cost is therefore a key element for understanding the role and purpose of economic organisation and institutions in a 'free' market economy.

Just as market participants face coordination costs derived from imperfect information, the regulator also faces an information-related coordination cost. The core characteristic of this information problem was identified by Hayek in his critique of central planning (Hayek, 1937, 1945). The central argument here is that the regulator's problem is an information problem because knowledge is dispersed in society and cannot be collected and fully conveyed to a central agency. The core argument is that it is costly to transfer knowledge to central agencies, and therefore, central agencies are likely to hold imperfect knowledge. 
Coase and Hayek therefore seem to be addressing the same issue from two different angles: the influence of imperfect information on economic organisation and efficiency. Just like a central regulator is handicapped by the lack of information, the same lack of information in companies handicaps the efficiency of the market through transaction costs. From this condition, Medema (2013) concludes:

"The problem, as Coase emphasised, is that both market and government coordination are costly, and neither will generate the optimal solutions contemplated by economic theory. Society thus faces a choice among imperfect alternatives and this, in turn, necessitates the adoption of a case-by-case, comparative institutional approach to the problems of economic policy." (Medema, 2013)

For convenience, we refer to these information-derived economic factors as the 'Coasian fundamentals' in the remaining text.

How do we then connect the Coasian fundamentals to the present problem of regulation and the four dimensions of regulation in Figure 1?

First, it should be evident that an assumption of full information makes considerations about communicative power obsolete. By contrast, communicative power has an obvious role when information is imperfect and dispersed.

Second, maybe as a less intuitive relationship, the assumptions about full information can also be linked to the neglection of the ownership power dimension in mainstream economics. The theoretical link is the following: In the absence of transaction costs, Coase shows in the article "The Problem of Social Costs" that the allocation of rights does not matter for the final allocation of goods and resources (Coase, 1960). However, as Coase highlights on several occasions, the transaction cost is present and is a fundamental theoretical concept for understanding economic organisation (Coase, 1937). It is widely recognised that the concrete forms of transaction costs come as search and information costs, bargaining costs, policing and enforcing costs, monitoring costs, etc. All these activities are directly related to the provision of knowledge in situations where full information is not present. In other words, transaction costs are directly linked to imperfect information. Thus, when transaction costs are accepted to be present it is incompatible with the neoclassical analytical approach founded on an assumption of full information.

The theoretical proof that Coase provided in the "Problem of Social Costs" is therefore the following: Only in a hypothetical world of zero transaction costs - full information - can the allocation of rights be ignored or neglected by economic theory. In the real world, where transaction costs are positive, the (ownership) rights and institutions must be part of the economic analysis always and everywhere (Djørup, 2020b). That is why Coase himself proposed in his Nobel Prize lecture that the concept of transaction costs had to lead to a revolution in economic theory (Coase, 1991). He also noted that this had not yet happened (Djørup, 2016).

While the debate often centres on how to create the most efficient state regulation when market conditions are hampered by monopolies, the scope of the present text is to highlight how ownership has played an important role in making existing price regulation work in the district heating sector.
Both the true cost regulation in Danish district heating and the alternative benchmarking models can in Hayekian terms be characterised as central planning mechanisms, where regulatory agencies try to decide on "correct costs".

Unlike the regulator, the regulated party typically holds more knowledge of the true costs. This condition of asymmetric information is a key hindrance to the Danish authorities' ability to price-regulate district heating companies, as experience has shown. Basically, they are dependent on the good will of the regulated company in order to succeed in the regulation. Or in other words, the interests of the regulator and the regulated party have to converge - in this case, low district heating consumer prices.

\subsection{INFORMATION, OWNERSHIP AND PRICE REGULATION OF DISTRICT HEATING}

While consideration of the Coasian fundamentals is at a very abstract and theoretical level, it is pertinent to outline the theoretical landscape in which we now turn to the more concrete and practical policy questions of regulating district heating monopolies. First, we will interpret the Coasian fundamentals in relation to the monopoly regulation problem. Thereafter, in the next section, we will dive into the empirical experiences of district heating monopoly regulation in Denmark.

Figure 2 illustrates how companies are regulated in a 'normal' market situation and Figure 3 in a monopoly situation. In a normal market situation, where ownership rights are not assigned to consumers, there is a conflict of interests and aims between the regulator, company and consumers. In the simplest version, companies have an interest in high prices while consumers and the regulator have an interest in low prices. The state regulative power is supplemented by consumer buying power in order to control the company and its prices. The consumer buying power is derived from competition between suppliers. Especially when the demand curve is steep, consumers' buying power is dependent on a competitive situation on the supply side.

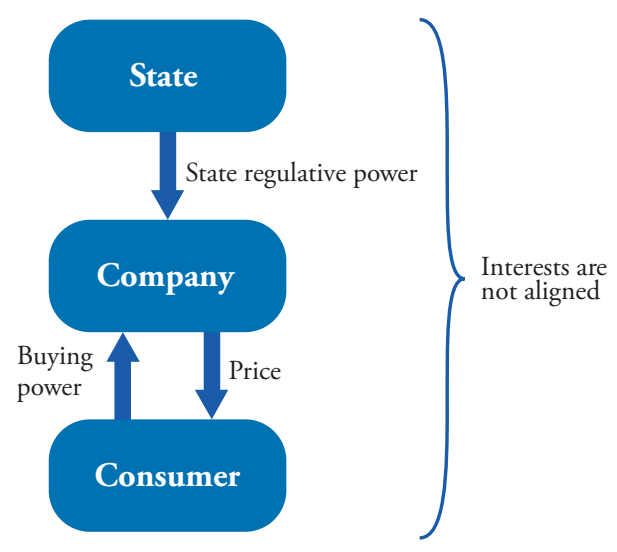

FIGURE 2. ILLUSTRATION OF MARKET REGULATION IN A NON-MONOPOLY SITUATION. SOURCE: DJØRUP (2020A). 
In the monopoly situation, the buying power of consumers is dismantled due to the monopoly situation. If consumers do not have ownership rights, only the state regulative power dimension is left to control the price level, which the company has an interest in increasing in order to maximise profits. Thus, the state often would try to implement some sort of regulated price through price cap models, true cost price regimes, benchmarking, etc.

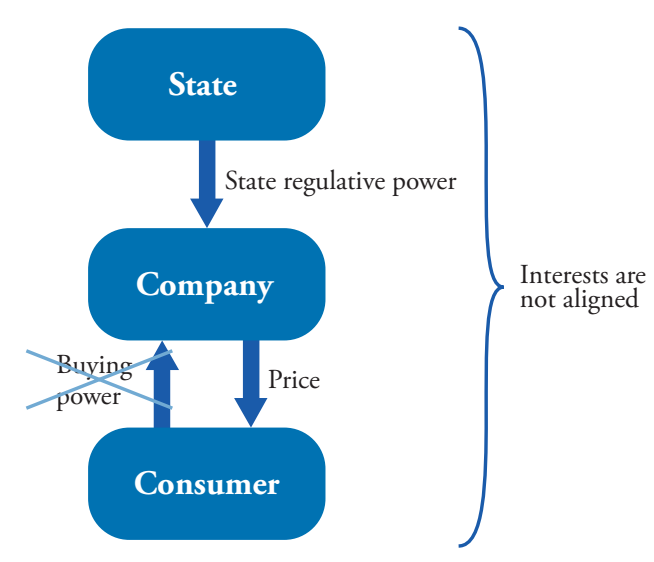

\section{FIGURE 3. ILLUSTRATION OF THE MONOPOLY CONDITION. SOURCE: DJØRUP (2020A).}

However, the state regulative power is limited by lack of information, since it is the regulated party - the company - that holds the full information on true costs. Since the interests of the company are not aligned with state and consumer interests, the company is not likely to fully disclose the full cost information which would allow the regulator to fully determine the correct price level.

Figure 4 illustrates how changes in ownership rights can become an important regulative dimension in such a monopoly situation. In the case of consumer ownership, the interest of the regulator, the company (the owners) and the consumers are the same: low prices. The change from private commercial ownership to consumer ownership improves the

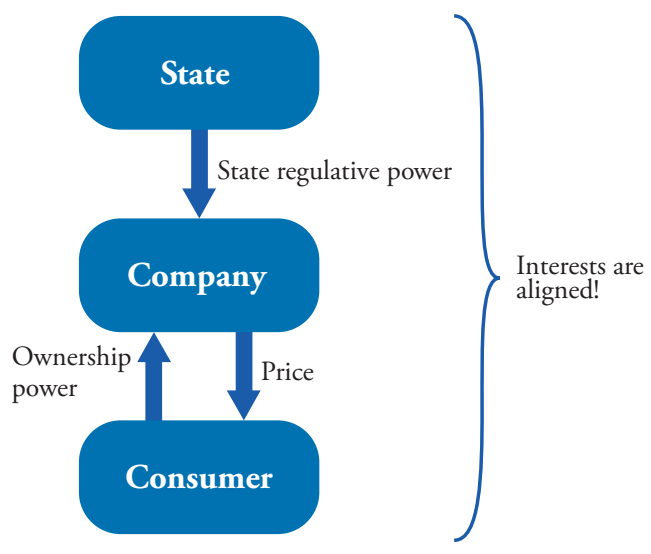

\footnotetext{
FIGURE 4. ILLUSTRATION OF THE MONOPOLY REGULATION IN THE CASE OF CONSUMER OWNERSHIP. SOURCE: DJØRUP (2020A).
}

price control. By supplementing the state regulative power directly with ownership power, and by enhancing the efficiency of state regulative power through a greater willingness to share and disclose information.

Further, there are more potential system benefits from consumer-owned companies and the willingness to share information. This may not only be important for the state to enforce a price regulation. It can also be important from an innovation perspective, as the geographically bounded consumer-owned monopolies are not direct competitors, but could achieve mutual gains through information sharing and collaboration.

In the following, we will analyse a case of private commercial ownership of district heating monopolies. By exploring this case, we provide lessons on how the state is hindered in enforcing its price regulation because of a) the asymmetric information between regulator and the regulated and b) the lack of interest alignment, which means that the company is not willing to share its information and collaborate. As will be shown, this has led to heavily inflated price levels for consumers. Before analysing the cases, we introduce some general statistical evidence that the consumer-owned companies - as expected in the theoretical approach above - have been more cost efficient and have provided lower prices for consumers. Afterwards, we provide a detailed description of how private commercial companies have avoided the price regulation, supplemented by descriptions of how a change in ownership improved the situation in several cases. Finally we summarise the findings and put them into the perspective of the ongoing Green Transition.

\section{LOWEST CONSUMER PRICES IN CONSUMER-OWNED DISTRICT HEATING COMPANIES}

In 2012, the Danish Energy Regulator Authority (DERA), later renamed to the Danish Utility Regulator (DUR), published a comprehensive analysis of consumer prices for all the country's district heating (DH) companies (DERA, 2012). The aim was to document the importance of the primary fuel source, urbanity, size of plant, and ownership for the consumer price. An economic regression analysis was made with an explanatory factor of $62 \%$. It is not possible on the basis of the analysis to determine whether the factors directly affect district heating prices or whether they are merely indicators of the factors affecting district heating prices. Thus the study must be taken with some precaution. This analysis is still the most thorough and comprehensive one ever done of consumer prices at Denmark's DH plants. The conclusion on ownership is summarized in Table 1.

As illustrated in Table 1, the directly consumer-owned DH companies offer slightly cheaper consumer prices than the municipality-owned DH companies (DKK 1,167 for a typical household), and much cheaper prices than the commercial DH companies (DKK 5,719). That is the additional price, when adjusted for the impact of fuel source, urbanity, and scale of production.

As the weighted average consumer prices for DH amounted to 13,359 DKK in the same period (Danish District Heating Association, 2015), the municipality-owned and commercial companies were roughly $9 \%$ and $43 \%$ more expensive than the consumer-owned DH companies, respectively. The price difference, especially compared to the commercial companies, is noteworthy. 


\section{TABLE 1. REGRESSION ANALYSIS OF ANNUAL CONSUMER PRICES ACCORDING TO OWNERSHIP OF DH COMPANIES, 2011/12}

\begin{tabular}{|l|c|}
\hline Ownership & Difference/year for standard heat customer (DKK) \\
\hline Consumer Cooperative & 0 (reference) \\
\hline Municipality-owned & $+1,167$ \\
\hline Commercial company & $+5,719$ \\
\hline
\end{tabular}

Note. Source: Authors calculation on data from DERA, 2012. For technical remarks, see appendix 1.

Later analyses have been conducted, but they are not of the same quality as the regression analysis mentioned above. All later analyses are based on average figures, and a large share of the commercial companies have been sold back to the consumers or municipalities, and are thus included in the categories of consumer-owned and municipality-owned DH companies. Furthermore, from 2018 onwards there are no statistics on commercial DH companies, as this category consists of a very limited number of companies, which is now included in the category of 'other ownership'.

However, an indication can be found in DUR's current statistics on $\mathrm{DH}$ prices. These have been used to analyse the consumer prices on a weighted average for each ownership category, but have not been adjusted for the impact of the primary fuel source, urbanity, and size of plant. Thus, the trend and not the nominal values of the heat prices will be noted. The consumer prices have changed during the 4 year period (2012/13 to 2016/17) as shown in Table 2:

Table 2 illustrates that the consumer-owned DH cooperatives continue to gain competitiveness in relation to the municipality-owned companies, and especially, compared to the commercial DH companies. The consumer-owned DH companies have delivered a $16 \%$ reduction in consumer prices over the four years, while the municipality-owned DH suppliers have delivered a 5\% reduction. In contrast, the consumer price at privately owned $\mathrm{DH}$ suppliers has increased by $7 \%$.

Thus, it can be concluded that there are significant differences in consumer prices depending on the ownership of the DH supplier. The most thorough examination, based on a regression analysis of all $\mathrm{DH}$ companies in Denmark in 2011/12, documents district heating supplied by commercial DH companies as being more than $40 \%$ more expensive than heat delivered by the consumer-owned DH companies. A later analysis of the 4 year period to $2016 / 17$ based on weighted average consumer prices indicates that the price differences according to ownership have increased even further.

The following sections shed light on the explanatory factors behind the rising heat prices at the commercial DH companies, and how the lack of consumer influence and control at these companies and insufficient regulation can contribute. Finally, it will be described, how the challenge of high $\mathrm{DH}$ prices can and has been solved.

\subsection{CASE STUDIES OF E.ON'S SHARPLY RISING CONSUMER PRICES IN CONSUMER-OWNED DISTRICT HEATING COMPANIES}

The reason behind the increase in consumer prices at the commercial DH companies is that most of these are/were owned by E.ON. Each of E.ON's DH companies was organized as a daughter company directly under the parent company. E.ON's DH companies made up a modest share of the total DH in Denmark. As DH is by far the main heat source in Denmark - 2/3 of all residential buildings are heated by $\mathrm{DH}$ - E.ON bought several DH companies, as outlined below.

This development started in the years around 2005, when the transnational energy company E.ON took over several Combined Heat and Power (CHP) plants in east Denmark, i.e. Zealand. Some plants were very small (e.g. Annebergparken), while others were of medium size (e.g. Frederikssund Kraftvarme). E.ON bought these CHP's (and a number of very small CHP units without a distribution network not mentioned here) from NESA, when NESA was merged with other energy companies.

\section{TABLE 2. ANALYSIS OF CONSUMER PRICES ACCORDING TO OWNERSHIP OF DH COMPANIES, 2012/13 TO 2016/17}

\begin{tabular}{|l|c|}
\hline Ownership & Change in comsumer price over 4 years for a standard heat customer \\
\hline Consumer Cooperative & $-16 \%$ (to 12,0037 DKK) \\
\hline Municipality-owned & $+5 \%$ (to 13,013 DKK) \\
\hline Commercial company & $+7 \%$ (to 13,459 DKK) \\
\hline
\end{tabular}

Note. For technical remarks, see appendix 1. Source: CEVEA (2018). CEVEA's calculation is based on data from DUR. 
Most of these companies increased their consumer price by $40-60 \%$ in the course of roughly 4 years from January 2009 onwards (DUR, 2018) - including the DH companies in Hjortekær, Gørløse, Skævinge, Ørslev Terslev, Annebjergparken, Slagslunde and other locations.

The consumers brought the case to DUR, which made a statement - i.e. a preliminary ruling - in June 2009 (DERA, 2009). It concluded that E.ON set its heating prices in an opaque and unreasonable manner.

This gave rise to thorough analyses and lengthy negotiations between DUR and E.ON. The Energy Appeals Board and the civil courts have also been involved due to numerous complaints and appeals from consumers in many localities. The case became subject to an increased political focus on the issue, which was partly spurred by the intense media coverage (The Climate, Energy and Building Committee, 2012) and a substantial investigation into E.ON's price setting by DUR.

DUR's preliminary ruling gave rise to a host of detailed analyses and legal disputes, which lasted for several years. The lengthy analyses of the entire case found that the consumer prices rose due to several factors, some of which are outlined below.

According to Danish DH regulation, the consumer prices must be the true costs of producing and distributing the heat. The true-cost principle has the disadvantage that privately owned $\mathrm{DH}$ companies have an incentive to boost expenses, as high costs will be covered by the consumers. The Danish regulation aims to prevent such behaviour by stipulating that all costs must be market conducive (Retsinformation, 2015; Terp, 2015). Thus, if a local DH company purchases fuel and services from a parent company, the prices must not be higher than the market price, in order to prevent unreasonable prices or transfer pricing.

However, Danish experience shows that the principle of non-profit costs can be circumvented, when daughter companies purchase equipment, fuel, and services from a parent company. There is no fixed definition of a 'market-conducive price'. Some actors purchase fuel, equipment and administrative services and obtain loans at relatively high prices, whereas others do so at relatively low prices. Thus, by selective price setting at the CHP's, it proved possible to increase the local DH costs and thus consumer prices substantially.

In order to prevent decisions on unfair price setting, the law prescribed that consumer representatives must be part of the board, where such decisions were made. But the consumer representatives in the board of 'E.ON Varme Danmark' were excluded from the mandatory board meetings, where important decisions on prices and delivery conditions were made. This restricted consumer influence, in violation of the Heat Supply Act and subsequent regulation. When DUR made this decision in January 2008 (DERA, 2010a), the consumers had been without influence for the entire period that E.ON had owned the heat supplies, i.e. for 2 years and 5 months.

Consequently, DUR sharply criticized these matters and decided to conduct stricter supervision of the company's compliance with the provisions on consumer influence until the end of 2009 (DERA, 2009).

- Furthermore, DUR could not obtain data and simple documentation for the actual costs. E.ON refused to give DUR access to these data. Therefore, the Heat Supply Act had to be amended in 2010 so DUR could monitor E.ON's prices and intra-corporation transactions. Only then could the case be advanced and investigated.
As mentioned, E.ON may only charge market prices for company-internal services. Therefore, E.ON's intra-corporation interest rate of $6.5 \%$ was investigated. This is of major importance, as the local E.ON subsidiaries borrowed the entire purchase price for the CHPs and the DH networks from the parent company. DUR considered the interest rate to be high in 2009, and perhaps too high, as the interest rate was declining in most financial markets. A dialogue was initiated, and E.ON changed the internal interest rate. From 2010, E.ON's intra-group interest rate was lowered to the interbank interest rate (CIBOR $)+2.5 \%$ (DERA, 2012).

Thus, when E.ON acquired NESA's DH supply in October 2005, an interest rate of $6.5 \%$ was used instead of the long-term bond yield, which DUR finds is usually the acceptable level of the interest rate. The difference between the two interest rates from 2005 to 2009 averaged 1.05 percentage points according to DUR's calculations. For the year 2011 , the newly applied interest rate $(\mathrm{CIBOR}+2.5 \%)$ was at $4.2625 \%$, which is substantially lower than the previous $6.5 \%$. This is of major importance to the fixed tariff on the consumer bill, as the daughter companies were $100 \%$ loan financed.

When E.ON bought a group of DH companies from NESA, the customers were promised that an existing guaranteed heat price for 20 years would continue under E.ON's ownership, even if the guaranteed price included a discount in relation to the cost-determined price. But E.ON cancelled the price guarantee on their own initiative and charged a higher heating price, which was a cost-determined price with reference to the Heat Supply Act's true cost (Allerslev, 2009; Energiankenævnet, 2013).

The Energy Appeal Board found that a private price agreement could not outweigh the price provisions of the Heat Supply Act, thus the heat price could increase to cover the true costs (Energy Body of Appeal, 2008). Thus, E.ON increased the price accordingly.

E.ON made consumers pay for investment costs that are higher than the actual costs. It should per se not be possible to charge more in depreciation than the actual costs. But it became possible, when E.ON bought the plants for a price lower than their value, i.e. actually depreciated costs. Due to a legal option in the Heat Supply Act, E.ON charged the consumers the same depreciation costs as if the plants were still owned by NESA, despite the fact that E.ON's depreciation costs were much lower due to low purchase prices.

The municipalities and consumers opted to sell the $\mathrm{DH}$ companies for a low price to E.ON, because they were promised lower consumer prices due to E.ON's professional management and economic largescale advantages. But the additional revenues from the higher depreciation costs were not used to lower consumer prices or to keep them stable. They were instead kept as liquid capital in the DH companies for E.ON's disposure.

Furthermore, it should be noted that E.ON charged consumers excessive interest payments, which DUR found was not in compliance with the Heat Supply Act and thus overturned. During the three years from $2006 / 2007$ to $2008 / 2009$, E.ON made consumers pay interest on the actually depreciated costs, even though the $\mathrm{DH}$ companies were bought and loan-financed for a much lower purchase price. E.ON could only make the consumers pay for interest on the loan actually borrowed from the parent company, not more (DERA, 2010b). 
Furthermore, E.ON's staff were provided from the parent company at relatively high costs, and the actual number of working hours was not recorded. In short, the administrative and other costs were unreasonably high compared to similar DH utilities. As an excessive example of this, each of the $90 \mathrm{DH}$ consumers at Annebergparken was charged 16,275 DKK in reported administration costs in 2009 (DERA, 2009).

A cursory examination confirms the excessive administrative costs. At E.ON's daughter company 'E.ON Production', the costs for administration and similar customer related services in 2010 were of the same size as the total in 71 open field DH plants ("barmarksverker") which are located in areas with relatively low heat densities and low heat demand volumes Another indicator for inflated administrative costs was illustrated when making a comparison with Horsens Fjernvarme. It had 4,900 district heating meters to manage - just slightly more than the total number of meters managed by the two daughter companies, 'E.ON Production' and 'E.ON Heating'. In 2009/2010, Horsens Fjernvarme spent a total of 4.9 million DKK on administration costs. This was one eighth of the total average costs for administration and other administrative costs at E.ON Production and E.ON Heating (DERA, 2012).

These indicative findings were later confirmed in another analysis based on E.ON's own reported data to the Danish District Heating association and open access to E.ON's administrative documents. E.ON's average administrative costs are about 4 times higher than other small-scale DH plants, while the maintenance costs are about 10 times higher, compared to other DH companies of similar size (Grøn Energi \& CEVEA, 2015).

Following these specific comparisons, DUR found that the administrative costs at E.ON Production and E.ON Heating must be reduced by $50 \%$. This compromise was a negotiated outcome that appears to have treated E.ON leniently, due to the fact that market conducive prices are difficult to set.

In sum, a few examples of E.ON's ways to increase its revenues and enforce transfer pricing have been given above, where the supervising authorities in several cases have intervened to the benefit of the consumers. But the Heat Supply Act and accompanying laws and decrees have for decades been based on the assumption that the $\mathrm{DH}$ sector was municipality and consumer-owned. Private DH companies are a relatively new development, and the regulation of private and commercial $\mathrm{DH}$ companies has proven insufficient and not ready to protect societal and consumer interests as intended by the Heat Supply Act. Furthermore, important differences in DUR's and the Energy Board of Appeal's legal interpretation of the Heat Supply Act have become apparent. This has, all-in-all, been an advantage to E.ON's large pool of legal staff and accounting expertise, which have successfully paved the way for dubious business mechanisms and creative law interpretations.

E.ON thereby managed to increase consumer prices or extract private profit out of its non-profit/consumer-profit DH companies. The above examples, which are not a comprehensive list, have illustrated that E.ON:

1) Cancelled the price guarantee given to consumers upon purchase of the DH companies

2) Applied a relatively high intra-corporation interest rate
3) Charged interest on the depreciated capital value even though the actual loan from the parent company was much lower

4) Charged consumers for investment costs higher than the actual DH company purchase costs

5) Charged unreasonably high administrative and other costs to consumers

6) Limited the availability of data and information on actual (intra-corporation) costs and services, and the Heat Supply Act was amended to ensure DUR such access in order to monitor prices and delivery conditions

7) Excluded consumer representatives from mandatory board meetings where important decisions with an impact on $\mathrm{DH}$ consumer prices were made.

As a result, municipalities and consumers have bought back the $\mathrm{DH}$ companies from E.ON in order to safeguard local DH consumers.

\subsection{SOLUTION: RE-TRANSFER OF OWNERSHIP FROM E.ON TO CONSUMERS}

Due to the public pressure from consumers and the local and national media, several municipal councils decided to buy back the crisis-ridden DH supplies in 2013. This resulted in lower consumer prices at several DH companies, as illustrated in Table 3.

As shown in Table 3, the six DH companies still owned by the private, transnational company experienced nearly unchanged or higher consumer prices during 2013.

The three DH companies that were transferred to municipal or consumer ownership saw declining prices in the range of 4,591 DKK to 18,788 DKK over the course of one year for a standard household. Thus, the problem was partly solved, when the municipalities decided to finance or buy (back) many crisis-ridden local DH companies from E.ON and integrate them into the municipality-owned energy companies or simply transfer the ownership to a consumer-owned heat company. According to the current rules, the benefits in terms of lower operating expenses from the derived economies of scale of an expanded DH supply can be accrued to the newly connected consumers for a maximum of 5 years, as long as it does not burden the existing consumers.

It is noteworthy that E.ON's DH companies were among the most expensive plants of all Denmark's DH companies. This is shown in Table 4.

In December 2012, E.ON owned 6 of Denmark's 9 most expensive $\mathrm{DH}$ companies, as shown in Table 4 . They were ranked as number 1 , 2, 3, 5, 7 and 9 on the list of $\mathrm{DH}$ companies with the highest consumer prices. This is remarkable, as E.ON owned only 9 of the total of 430 $\mathrm{DH}$ companies, which have submitted prices to DUR as a mandatory requirement.

One year later, in December 2013, E.ON still owned 3 of the 4 most expensive $\mathrm{DH}$ utilities. Three other companies previously in the top 9 


\section{TABLE 3. DH CONSUMER PRICES FOR DH COMPANIES OWNED OR PREVIOUSLY OWNED BY E.ON (DKK PER YEAR)}

\begin{tabular}{|c|c|c|c|c|}
\hline Name of DH company & $\begin{array}{c}\text { DH price: } \\
15 \text { Dec. } 2013\end{array}$ & $\begin{array}{c}\text { DH price: } \\
18 \text { Dec. } 2012\end{array}$ & $\begin{array}{l}\text { Change in } \\
\text { DH price }\end{array}$ & Change in ownership \\
\hline Hjortekær & 37,090 & 37,096 & -6 & No. Privately owned \\
\hline Annebergparken & 31,793 & 31,803 & -10 & No. Privately owned \\
\hline $\begin{array}{l}\text { Ørslev-Terslev } \\
\text { Kraftvarmeforsyning }\end{array}$ & 31,041 & 31,005 & 36 & No. Privately owned \\
\hline Slagslunde Kraftvarmeværk & 25,614 & 30,205 & -4.591 & $\begin{array}{l}\text { Yes. Consumer group } \\
\text { buys DH supply }\end{array}$ \\
\hline Præstø Fjernvarme & 23,573 & 21,329 & 2.244 & No. Privately owned \\
\hline $\begin{array}{l}\text { Lendemarke } \\
\text { Varmeforsyning }\end{array}$ & 18,971 & 13,151 & 5.820 & No. Privately owned \\
\hline $\begin{array}{l}\text { Skævinge } \\
\text { Fjernvarmeforsyning }\end{array}$ & 17,178 & 27,901 & -10.724 & $\begin{array}{l}\text { Yes. Municipality buys } \\
\text { DH supply. }\end{array}$ \\
\hline Frederikssund Kraftvarme & 17,653 & 17,653 & 0 & No. Privately owned \\
\hline Gørløse Fjernvarme & 16,338 & 35,125 & -18.788 & $\begin{array}{l}\text { Yes. Municipality buys } \\
\text { DH supply. }\end{array}$ \\
\hline
\end{tabular}

Note. The calculation is based on data from DERA. For technical remarks, see appendix 1.Consumer prices are listed for a typical house (130 m², 18.1 MWh heat consumption). 1 Euro - 7.5 Danish Kroner. Source: Odgaard and Djørup (2020).

\section{TABLE 4. RANKING OF DH CONSUMER PRICES FOR DH COMPANIES OWNED OR PREVIOUSLY OWNED BY E.ON}

\begin{tabular}{|c|c|c|c|}
\hline Name of DH company & $\begin{array}{l}\text { DH price in DK } \\
(1=\text { highest } \\
\text { consum. price): } \\
18 \text { Dec. } 2012\end{array}$ & $\begin{array}{c}\text { DH price in DK } \\
(1=\text { highest } \\
\text { consum. price): } \\
15 \text { Dec. } 2013\end{array}$ & Change in ownership \\
\hline Hjortekær & 1 & 1 & No. Privately owned \\
\hline Annebergparken & 3 & 3 & No. Privately owned \\
\hline $\begin{array}{l}\text { Ørslev-Terslev } \\
\text { Kraftvarmeforsyning }\end{array}$ & 5 & 4 & No. Privately owned \\
\hline Slagslunde Kraftvarmeværk & 7 & 13 & $\begin{array}{l}\text { Yes. Consumer group buys } \\
\text { DH supply }\end{array}$ \\
\hline Præstø Fjernvarme & 55 & 27 & No. Privately owned \\
\hline Lendemarke Varmeforsyning & 335 & 102 & No. Privately owned \\
\hline $\begin{array}{l}\text { Skævinge } \\
\text { Fjernvarmeforsyning }\end{array}$ & 9 & 161 & $\begin{array}{l}\text { Yes. Municipality buys } \\
\text { DH supply. }\end{array}$ \\
\hline Frederikssund Kraftvarme & 137 & 166 & No. Privately owned \\
\hline Gørløse Fjernvarme & 2 & 209 & $\begin{array}{l}\text { Yes. Municipality buys } \\
\text { DH supply. }\end{array}$ \\
\hline
\end{tabular}

Note. For technical remarks, see appendix 1. Source: The ranking was made by the authors, based on data from DERA, (2018). 
were bought back by a municipality and a consumer coop. Their ranks changed from 7 to 13,9 to 161 and 2 to 209 among Denmark's 430 $\mathrm{DH}$ companies. The somewhat modest decline from number 7 to 13 happened in the consumer-owned plant in Slagslunde, where the newly elected board preferred to analyse its options in greater detail, before an attractive and sustainable solution was implemented a few years later. The case of Slagslunde is described below.

This beneficial trend of consumer and municipality ownership continued in the following years. Thus, the DH company in Præstø was taken over by consumers in 2014. The DH utility in Anneberg was sold to the Nykøbing Sjælland consumer coop in 2016. Lower consumer prices were thereby obtained, although the Præstø DH utility has met some special technical difficulties on its path to lower consumer prices.

The re-transfer of ownership for these plants was possible due to a special municipal credit scheme in Denmark (KommuneKredit). This credit institution, which is jointly owned by all municipalities, operates on a non-profit basis and offers financing at 2-3 percentage points lower than normal commercial loans. Consumer coops are also eligible for these credits.

The general trend has been that when a DH plant was integrated in the municipality-owned DH supply, the consumer price declined rapidly, as the organizational and often technical set-up was ready from the start. But the transfer to a consumer-owned DH company typically resulted in lower consumer prices after a few years, because a feasibility study and the installation of new technological solutions had be undertaken first.

\subsubsection{E.ON FORCED TO SETTLE DISPUTES AT THEIR REMAINING PLANTS}

Four of E.ON's DH companies were not sold back to consumers.

Faxe Municipality assisted Ørslev-Terslev Kraftvarmeforsyning to search for possible solutions, and new measures were identified to achieve lower heating prices. However, the municipality and the consumers could not reach an agreement with E.ON on the purchase price and other preconditions. Furthermore, a large share of the consumers had decided to opt out of the DH supply, as their confidence in continued DH had seriously deteriorated.

Lendemarke DH company entered negotiations with Vordingborg municipality about an integration with the municipality-owned heat supply, but the final negotiations reached an impasse. Similarly, the DH plant in Frederikssund negotiated with their municipality council about a solution, but stopped before detailed negotiations.

Therefore, E.ON came up with a new organizational set-up for the 4 remaining DH companies: Ørslev-Terslev, Lendemarke, Frederikssund and Hjortekær. Only when the most apparent alternative solutions and transfer of ownership had been attempted to no avail, E.ON demonstrated its ability to come up with true solutions.

E.ON established a common economic framework for all $4 \mathrm{DH}$ plants, effective from 1 January 2016. The costs for administration were lowered, cheap industrial surplus heat was exploited and new investments in biomass boilers and solar panels etc. were undertaken. This has lowered the average heating price significantly.
It should be noted that E.ON's initiative to lower the heat price of some of their last, remaining plants has not been driven by regulatory incentives or measures. Rather, it is due to persistent criticism from consumers and the press, and a continuous involvement of both lo$\mathrm{cal}$ and national politicians. E.ON's earnings from the few remaining plants may be relatively negligible, but the costs of continuous poor PR could affect its other businesses adversely.

\subsection{CASE STUDY OF HOW THE CONSUMER- OWNED DH COMPANY AT SLAGSLUNDE ACHIEVED LOW CONSUMER PRICES}

Slagslunde DH is a small, consumer-owned cooperative on Zealand servicing $237 \mathrm{DH}$ consumers, with an annual production of $5.6 \mathrm{GWh}$ heat. The company was purchased by E.ON in 2005 and re-established as a consumer cooperative in 2013, when the consumers bought the company back at a price of 13 million DKK. Between 2004 and 2010, the DH price for a standard house increased from 19,221 DKK to 30,199 DKK (10\% per year), peaking at 39,775 DKK in 2011 (Madsen, 2019). This corresponds to a more than $100 \%$ price increase over the course of 6 years.

The high heating costs not only meant high running costs for consumers, but also made it near impossible to sell houses in the area, as opting out of DH was very costly. Nevertheless, the number of DH consumers dropped slightly from 2005-2013, putting extra economic pressure on the remaining consumers. As elsewhere, E.ON justified these price increases with high administration costs, high intra-company interest rates and a non-transparent and dubious depreciation practice (Madsen, 2019). In addition, the maintenance of the $\mathrm{DH}$ grid and customer installations was deficient, leading to high grid losses. By 2013, E.ON had accumulated a deficit of DKK 6 million in the DH company, which would have to be covered by consumers as well in the case of a purchase of the company.

In 2015, two years after the re-transfer of the DH company to the consumers, the average heat price had been reduced by $33 \%$ - mainly by lowering administration costs and minor technical modifications. In fact, administration costs were reduced by $75 \%$ from DKK 1 million to 0.25 million. This was made possible by receiving assistance for operating the $\mathrm{DH}$ plant from another local DH company, lowering staff costs for maintenance personnel, and voluntary work by the new company board. Whereas the water loss in the $\mathrm{DH}$ grid was 2,000 1 per day prior to the re-transfer, it was reduced to 91 per day in 2016. Moreover, a new temperature control system is helping save natural gas at the CHP and boiler units (Drachmann, 2016; Frederiksborg Amts Avis, 2014; Lokalavisen Egedal Weekend, 2015).

The DH company now also works more closely with energy efficiency at the customer level. Smart heat meters have been installed, customers can get a visit by the plant manager to check their heat installations, and insulation of the $\mathrm{DH}$ connection pipes has been added at many houses (Madsen, 2019). It is interesting to note that all of these solutions are "low tech" and can be considered standard practice. As a result, the standard DH price was lowered to 17,725 DKK in 2016 - a $55 \%$ reduction in the space of three years.

Other benefits of the re-transfer include a slight increase in the number of $\mathrm{DH}$ connections, a considerable increase in house sales, and large 
heat cost savings for the municipality, which owns some buildings in Slagslunde (Frederiksborg Amts Avis, 2017). Also, while prior to the sale no direct efforts were made to reduce the dependence on natural gas, Slagslunde DH is now actively considering options to phase out natural gas, such as biomass and heat pumps.

A similar development in heat prices and DH utility efficiency can be witnessed in Gørløse and Skævinge - two DH companies that were re-transferred from E.ON to the municipal DH company Hillerød Forsyning. After the re-transfer in 2013, the large price decreases (Table 3) for the DH customers in Skævinge and Gørløse were possible because these plants were integrated into the large DH supply area of Hillerød and connected with a DH transmission pipe. Also here, the re-transfer only happened after lengthy negotiations with E.ON, where Hillerød Forsyning succeeded in only paying for the non-depreciated value of the plants - and not more, as E.ON required (Møller-Hansen, 2019).

\subsection{MEANS TO ENHANCE EFFICIENCY AND GREEN INVESTMENTS IN CONSUMER-OWNED COMPANIES}

As shown above, the consumer-owned DH utilities have demonstrated a multiyear commitment to serve consumers with cheap $\mathrm{DH}$, also in former very expensive $\mathrm{DH}$ companies under private ownership. The facts do not point to consumer-owned enterprises having no incentives to provide cheap and affordable heat to customers - on the contrary. There are several reasons behind this.

Firstly, the heat regulation entails a number of means and incentives to ensure low costs when selling heat for true costs (Odgaard \& Djørup, 2020):

- Mandatory use of a standardized and quality assured feasibility study as part of the approval procedure (although some of the procedures could be made more simple and user-friendly)

- Public hearings for the DH project proposal, including the feasibility study, ensure popular involvement and confidence

- Guaranteed third party access, if cheaper heat supply can be documented

- Actual costs are covered by the consumer heat prices, which ensures maintenance and re-investment

- A fixed tariff and/or connection fee ensures repayment of the capital investment

- Subsidies are passed on directly to DH plants and consumers, which prevents the risk of local government expropriation of central state subsidies

- Open access to data and standardised consumer price benchmarks ensures transparency and thus popular support

- Voluntary economic performance benchmarks by the national branch organization and information on new, more effective solutions at other plants are disseminated by the branch organization
- Independent central authorities to monitor prices and handle complaints (although they seem understaffed).

Secondly, experiences over several years show that most boards on the consumer-owned DH plants are well functioning. They do actively pursue cheaper consumer prices, as all cost reductions are entirely converted into cheaper consumer prices due to the non-profit/consumer-profit management. Public disclosure of changes in consumer prices at all $\mathrm{DH}$ plants at least twice a year sets the board under pressure, as the local media always compare the heat prices at neighbouring plants. The boards are directly elected by the consumers, and low consumer prices are often rewarded by high status and esteem in the local communities. Such sociological explanatory factors must not be neglected in the mainstream economic argument of the importance of competition - homo sociologicus must accompany homo economicus.

Thirdly, the local organizational set-ups matter greatly. On the positive side, a few people with extraordinary enthusiasm can often mobilize support and organize the initiation and realization of local $\mathrm{DH}$ projects, which was an important factor in the 1990's rapidly growing decentralized DH sector. On the negative side, a rule of thumb is that $5-10 \%$ of the consumer-owned coops are run inefficiently. Personal disputes in the board or lack of special skills in special situations may hinder new solutions and adoption of more efficient measures. Several plants have experienced a local 'king on the mountain', who opposes sensible measures and cooperation with neighbouring plants on joint administration and pooled gas purchases, etc. But the vast majority of the plants are actually run really soundly.

In recent years, the government ministries have recommended regulatory benchmarking and other very detailed economic management of the decisions of DH plants as an efficiency enhancing measure (Ministry of Climate, Energy and Buildings, 2017, 2016). This may prove counterproductive, if these policies are finally decided (scheduled for political negotiations before the end of 2020) and implemented. The suggested detailed economic management with individual price caps etc. for each DH company are highly controversial in the DH sector, as the tools are too inaccurate and superficial to set proper benchmarks and price caps. The critical issues with regulatory benchmarking and price caps are: 1) The data used to set the price cap for the coming year(s) are several years old and may be outdated. 2) The number of similar DH companies is often too small to set precise benchmarks. The district heating companies are very different with regard to size, fuels, technologies, and co-production of heat with electricity and/or cooling etc. This leads to hundreds of unique combinations of technology and fuels in various sizes (Hougaard \& Rønde, 2018). 3) The transaction costs in terms of supervisory bodies and centrally employed staff are very high. The likely outcome is lengthy processes with negotiated prices between the supervising national authorities and each company board. The criticism from the DH plants and their branch organization has been profound, as they regard such regulation as unnecessary bureaucratic, costly, time-consuming and inefficient.

Instead, there is an obvious and very effective way to enhance efficiency, lower consumer prices and provide economic means and local focus on new green technologies: A task force which could promote new solutions on a permanent and national scale. For example, a national task force was staffed at the Danish Energy Agency to promote large-scale heat pumps as a means to assist the decentralized DH plants in reducing consumer prices and promote new green technologies. This took place from 2015 to 2018 and is widely regarded as a very successful measure 
(Danish Energy Agency, 2018). A similar but larger task force could assist all or selected decentralized DH plants in introducing other new technologies, and expand its scope to give advice also on management and the exploitation of large-scale advantages by new organizational set-ups etc. The task force could cooperate with the branch organization, which enjoys support from most $\mathrm{DH}$ companies around Denmark. Such non-bureaucratic measures, which have proven their efficiency and are regarded with confidence by most DH plants, warrant attention, as the costs for such an initiative will be only a fraction of the large system with regulatory benchmarking etc.

Note that the branch organization has been an important and trustworthy advisor for the plants for decades. The Danish District Heating Organization has established their own project organization, which can assist members with highly qualified and cheap technical advice and other matters upon request. Legal advice and guidelines in organizational issues are also provided.

\section{CONCLUSIONS AND IMPLICATIONS FOR THE GREEN TRANSITION}

In the transition to renewable energy systems, the heating sector is very important, as a large part of the total energy demand is located in the heating sector, with ample opportunities to pave the way for a greener energy sector - both in countries with or without an existing DH infrastructure.

Both for new and transitional DH systems, consumer trust is an indispensable factor. For new systems, consumers would naturally have to accept being enrolled in a new monopoly structure. For transitional systems, low temperature DH systems must be developed in order to create synergies between renewables, waste heat resources and energy savings. Thus, neither new nor transitional DH systems can be realised without consumer involvement and trust.

Consumer trust is dependent on the regulation - and the efficiency of any state regulation is dependent on information. In order to control monopoly prices, the state would need access to adequate levels of information on the true costs of the district heating operation.

The cases in Denmark have shown that lack of information for state authorities has been a serious issue when district heating systems are operated by private commercial companies. The examples presented in this text have demonstrated that the information control advantages of district heating companies can be used to avoid the existing price regulation. The combination of true cost price regulation and commercial ownership of district heating systems has been a big regulatory failure. The information asymmetry combined with a profit motive inflated consumer prices, while state authorities were unable to sufficiently monitor and/or prove the existence of monopoly abuse.

Such regulatory failures are a barrier to the Green Transition since they undermine consumers trust in district heating. Infrastructure which is important to a sustainable future can thereby become politically infeasible, even though its environmental and economic advantages are well documented.
Theoretically, commercial ownership can only be fully controlled through state regulative power in a condition of full information, i.e. when the regulator possesses full knowledge of the true costs. This is the theoretical condition in neoclassical economics. Regulative discussions can hardly neglect the Coasian fundamentals that we introduced in the theoretical approach; i.e. the regulator lacks information and any collection of information is costly. The empirical examples in this article demonstrate and underline these theoretical points, which can hardly be ignored by theoretical work aiming to support policy development for a sustainable transition.

The essence of these theoretical points goes beyond the Danish true cost price regulation. In the absence of consumer ownership power, the state regulative power has been incapable of monitoring true costs and has therefore been unable to enforce its price regulation policy. The necessity of monitoring true cost would also be present in other variations of state price regulation. Various benchmarking models also rely on conveying adequate levels of information to the centralised agency. The Danish experience shows, based on the presented empirical material, that the state regulative power needs backing from ownership models which provide alignment between interests and willingness to collaborate. Future research could, and probably will, investigate ingenious theoretical regulatory concepts to make the state regulation less dependent on ownership models. However, our presumption is that the Coasian fundamentals remain, and the consumer ownership model in the Danish district heating sector provides lessons for both theory and policy.

\section{APPENDIX 1. TECHNICAL REMARKS FOR TABLE 1}

The heat prices are for a standard heat customer with an annual heat consumption of $18.1 \mathrm{MWh} / 65 \mathrm{TJ}$ for a typical house of $130 \mathrm{~m}^{2}$. A linear regression model has been estimated with the district heating price for a standard single-family house as a dependent variable and with a primary fuel source, urbanity, ownership and size as explanatory variables. The first three variables are included as so-called dummy variables. The size is included as a transformed continuous variable, as this functional form statistically best describes the relationship between size and price. In addition, the functional form is otherwise useful for describing the occurrence of any scale/economies of scale. The regression is based on 431 observations from Danish DH utilities in 2011/12.

\section{REFERENCES}

Allerslev, M. L. (2009). Henvendelse til Det Energipolitiske Udvalg, 14 February 2009. Retrieved from https://www.ft.dk/samling/20081/almdel/EPU/bilag/178/645193.pdf.

Barry, M., \& Chapman, R. (2009). Distributed small-scale wind in New Zealand: Advantages, barriers and policy support instruments. Energy Policy, 37(9), 3358-3369. https://doi. org/10.1016/j.enpol.2009.01.006.

Coase, R. H. (1937). The Nature of the Firm. Economica, 4(16), 386-405. https://doi. org/10.2307/2626876,

Coase, R. H. (1960). The Problem of Social Cost. Journal of Law and Economics, 3, 1-44. https://doi.org/https://doi.org/10.1086/466560.

Coase, R. H. (1991). Prize Lecture: The Institutional Structure of Production. Retrieved from http://www.nobelprize.org/nobel_prizes/economic-sciences/laureates/1991/coase-lec$\underline{\text { ture.html. }}$ 
Connolly, D., Lund, H., Mathiesen, B. V., Werner, S., Möller, B., Persson, U., ... Nielsen, S. (2014). Heat Roadmap Europe: Combining district heating with heat savings to decarbonise the EU energy system. Energy Policy, 65, 475-489. https://doi.org/10.1016/j. enpol.2013.10.035.

Danish District Heating Association. (2015). Data submitted to Ole Odgaard at the Danish Energy Agency by Senior Advisor John Tang from Danish District Heating Association.

Devine-Wright, P. (2005). Local aspects of UK renewable energy development: Exploring public beliefs and policy implications. Local Environment, 10(1), 57-69. https://doi.org/ 10.1080/1354983042000309315.

Djørup, S. (2016). Fjernvarme i forandring (Ph.d.-seri). Aalborg Universitetsforlag. https:// doi.org/10.5278/vbn.phd.engsci.00137.

Djørup, S. (2020a). Ownership Structure, Financing, and Regulation for District Heating and Cooling: Experience and Innovative Approaches. IRENA. Retrieved from https:// irena.org/events/2020/May/Integration-of-Low-Temperature-Renewable-Energy-Sources-into-District-Heating-and-Cooling-Systems.

Djørup, S. (2020b). The Institutionalisation of Zero Transaction Cost Theory: A Case Study in Danish District Heating Regulation. Evolutionary and Institutional Economics Review, In press/P. https://doi.org/https://doi.org/10.1007/s40844-020-00164-3.

Djørup, S., Sperling, K., Nielsen, S., Østergaard, P. A., Thellufsen, J. Z., Sorknæs, P., ... Drysdale, D. (2020). District Heating Tariffs, Economic Optimisation and Local Strategies during Radical Technological Change. Energies, 13(Selected Papers from SDEWES 2019 conferences on Sustainable Development of Energy, Water and Environment Systems), 1-15. https://doi.org/https://doi.org/10.3390/en13051172.

Drachmann, H. (2016). Privatisering fordoblede varmeregning. Politiken, Sektion 1, p. 5.

Energiankenævnet. (2013). Afgørelse. Sag: 12/05442. Retrieved from https://www.energianke.dk/media/46558/12-05442-anonym.pdf.

Energiklagenævnet. (2008). Afgørelse. "Slagslunde Fjernvarmelaug over Energitilsynet af 25. oktober 2007 prisen for varme fra E.ON Varme Danmark ApS."

Energistyrelsen. (2018). Rejsehold for store varmepumper. Retrieved from https://ens.dk/ ansvarsomraader/varme/rejsehold-store-varmepumper.

Energitilsynet. (2009). Energitilsynets undersøgelse af E.ON’s pris-fastsættelse - resumé. Retrieved from https://forsyningstilsynet.dk/media/3640/eons-prisfastsaettelse.pdf.

Energitilsynet. (2010a). E.ON Varme ApS - tilkendegivelse om anlægsværdierne mv. efter varmeforsyningsloven vedr. anlæg overtaget fra NESA. Retrieved from http://sflinfo.dk/cms/ sites/default/files/egen_drift/ET_tilkendegivelse_anlaegsvaerdier_varme_100408.pdf.

Energitilsynet. (2010b). Status på det skærpede tilsyn vedr. forbrugerindflydelse i E.ON Varme Danmark Aps. Retrieved from https://forsyningstilsynet.dk/media/3600/eon_forbrugerindsflydelse.pdf.

Energitilsynet. (2012). E.ON's koncerninterne samarbejdsaftaler, 26. juni 2012. Retrieved from https://forsyningstilsynet.dk/media/3577/tilkendegivelse_eon_26_jun.pdf.

Energitilsynet. (2013). Store forskelle i varmepriserne - hvorfor ? Retrieved from http://energitilsynet.dk/varme/artikler-og-analyser/varmeprisanalysen-2013/.

Forsyningstilsynet. (2018). Varmepriser. Retrieved from https://forsyningstilsynet.dk/tal-fakta/priser/varmepriser.

Frederiksborg Amts Avis. (2014). Succes hos varmeværk sænker varmepriserne. Frederiksborg Amts Avis, p. 13.

Frederiksborg Amts Avis. (2017). Varm hilsen til byrådet. Frederiksborg Amts Avis, Sektion 2, p. 16.

Gorroño-Albizu, L. (2020). The benefits of local cross-sector consumer ownership models for the transition to a renewable smart energy system in Denmark. An exploratory study. Energies, 13(6). https://doi.org/10.3390/en13061508.

Gorroño-Albizu, L., Sperling, K., \& Djørup, S. (2019). The past, present and uncertain future of community energy in Denmark : Critically reviewing and conceptualising citizen ownership. Energy Research \& Social Science, 57(July), 101231. https://doi.org/10.1016/j. erss.2019.101231.

Grøn Energi, \& CEVEA. (2015). Kommercialisering eller samfundsnytte? Fjernvarmen under lup. Retrieved from https://www.danskfjernvarme.dk/groen-energi/analyser/kommercialisering-eller-samfundsnytte-fjernvarmen-under-lup.

Hayek, F. A. (1937). Economics and Knowledge. Economica IV.

Hayek, F. A. (1945). The Use of Knowledge in Society. American Economic Review.
Hoicka, C. E., \& MacArthur, J. L. (2018). From tip to toes: Mapping community energy models in Canada and New Zealand. Energy Policy, 121(November 2017), 162-174. https://doi.org/10.1016/j.enpol.2018.06.002.

Hougaard, J. L., \& Rønde, T. (2018). Benchmarking af fjernvarmesektoren. Retrieved from https://www.danskenergi.dk/sites/danskenergi.dk/files/media/dokumenter/2018-11/ Benchmarking_af_fjernvarmesektoren_analyseNov2018.pdf.

Hvelplund, F., \& Djørup, S. (2019). Consumer ownership , natural monopolies and transition to $100 \%$ renewable energy systems. Energy, 181, 440-449. https://doi. org/10.1016/j.energy.2019.05.058.

Klima- Energi og Bygningsministeriet. (2016). Stemmeaftale om regulering af fjernvarmesektoren, 7. april 2016. Retrieved from https://kefm.dk/media/7378/aftale_om_ny_regulering_paa_fjernvarmeomraadet.pdf.

Klima- Energi og Bygningsministeriet. (2017). Stemmeaftale om økonomisk regulering af fjernvarmesektoren, 2. juni 2017

Klima- Energi og Bygningsudvalget. (2012). Åbent brev til klima-, energi- og bygningsminister Martin Lidegaard. Retrieved from Åbent brev til klima-, energi- og bygningsminister Martin Lidegaard.

Kooij, H.-J., Oteman, M., Veenman, S., Sperling, K., Magnusson, D., Palm, J., \& Hvelplund, F. (2018). Between grassroots and treetops: Community power and institutional dependence in the renewable energy sector in Denmark, Sweden and the Netherlands. Energy Research and Social Science, 37. https://doi.org/10.1016/j.erss.2017.09.019.

Krog, L., Sperling, K., Svangren, M. K., \& Hvelplund, F. (2020). Consumer involvement in the transition to $4^{\text {th }}$ generation district heating. International Journal of Sustainable Energy Planning and Management, 29, 141-152. https://doi.org/10.5278/ijsepm.4627.

Lokalavisen Egedal Weekend. (2015). Borgerdrevet varmeværk har skabt store besparelser. Lokalavisen Egedal Weekend, Sektion 1, p. 2.

Lund, H., Alberg, P., Chang, M., Werner, S., Svendsen, S., Sorknæs, P., ... Duic, N. (2018). The status of $4^{\text {th }}$ generation district heating: Research and results, 164. https://doi. org/10.1016/j.energy.2018.08.206.

Lund, H., Hvelplund, F., Mathiesen, B. V., Østergaard, P. a., Christensen, P., Connolly, D., ... Lind, M. (2011). Coherent Energy and Environmental System Analysis. Retrieved from www.ceesa.dk/Publications.

Lund, H., Werner, S., Wiltshire, R., Svendsen, S., Thorsen, J. E., Hvelplund, F., \& Mathiesen, B. V. (2014). $4^{\text {th }}$ Generation District Heating (4GDH). Integrating smart thermal grids into future sustainable energy systems. Energy. Elsevier Ltd.

MacArthur, J., \& Matthewman, S. (2018). Populist resistance and alternative transitions: Indigenous ownership of energy infrastructure in Aotearoa New Zealand. Energy Research and Social Science, 43(May), 16-24. https://doi.org/10.1016/j.erss.2018.05.009.

Madsen, K. (2019). "Ejerskabsforhold i fjernvarmen”. Presentation at the Annual Meeting of the Danish District Heating Association. Aalborg.

Meade, R., \& Söderberg, M. (2020). Is welfare higher when utilities are owned by customer instead of investors? Evidence from electricity distribution in New Zealand. Energy Economics, 86, 104700. https://doi.org/10.1016/i.eneco.2020.104700.

Medema, S. (2013). Finding his own way: Ronald Coase (1910-2013). Retrieved June 28 , 2016, from http://voxeu.org/article/coase-theorem-and-economics-coase.

Møller-Hansen, A. B. (2019). Overtagelse af "Barmarksprojekter" nær Hillerød. In Presentation at the Annual Meeting of the Danish District Heating Association, October 24, 2019, Aalborg. Aalborg.

Möller, B., Wiechers, E., Persson, U., Grundahl, L., \& Connolly, D. (2018). Heat Roadmap Europe: Identifying local heat demand and supply areas with a European thermal atlas. Energy, 158, 281-292. https://doi.org/10.1016/J.ENERGY.2018.06.025.

Möller, B., Wiechers, E., Persson, U., Grundahl, L., Lund, R. S., \& Mathiesen, B. V. (2019). Heat Roadmap Europe: Towards EU-Wide, local heat supply strategies. Energy, 177, 554-564. https://doi.org/10.1016/j.energy.2019.04.098.

Odgaard, O., \& Djørup, S. (2020). Review of price regulation regimes for district heating. International Journal of Sustainable Energy Planning and Management. https://doi.org/ http://dx.doi.org/10.5278/ijsepm.3824.

Paardekooper, S., Lund, R. S., Mathiesen, B. V., Chang, M., Reinert, U., Grundahl, L., .. Persson, U. (2018). Heat Roadmap Europe 4. Quantifying the Impact of Low-Carbon Heating and Cooling Roadmaps. Retrieved from https://vbn.aau.dk/da/publications/ heat-roadmap-europe-4-quantifying-the-impact-of-low-carbon-heatin. 
Persson, U., Möller, B., \& Werner, S. (2014). Heat Roadmap Europe: Identifying strategic heat synergy regions. Energy Policy, 74(C), 663-681. https://doi.org/10.1016/j.enpol.2014.07.015.

Retsinformation. (2015). Bekendtgørelse af lov om varmeforsyning. Retrieved from https:// www.retsinformation.dk/forms/r0710.aspx?id=165652.

Rogers, J. C., Simmons, E. A., Convery, I., \& Weatherall, A. (2008). Public perceptions of opportunities for community-based renewable energy projects. Energy Policy, 36(11), 4217-4226. https://doi.org/10.1016/j.enpol.2008.07.028.
Terp, S. (2015). Indregningsberettigede udgifter efter varmeforsyningslovens $\$ 20$ (The Cost of Heat - Allowed expenses under $₫ 20$ of the Danish heat supply act). Retrieved from https://law.au.dk/fileadmin/Jura/dokumenter/forskning/rettid/Afh_2015/afh232015.pdf.

Warren, C. R., \& McFadyen, M. (2010). Does community ownership affect public attitudes to wind energy? A case study from south-west Scotland. Land Use Policy, 27(2), 204-213. https://doi.org/10.1016/j.landusepol.2008.12.010. 